Acta Universitatis Wratislaviensis No 4052

PRAWO CCCXXXII

Wrocław 2021

https://doi.org/10.19195/0524-4544.332.2

MATEUSZ SZYMURA

ORCID: 0000-0001-7146-8477

Uniwersytet Wrocławski

mateusz.szymura@uwr.edu.pl

\title{
John Erskine z Carnock (1695-1768) - adwokat, profesor Uniwersytetu w Edynburgu, pisarz instytucjonalny
}

\section{Pochodzenie i młodość Johna Erskine’a}

O życiu Johna Erskine'a z Carnock wiadomo stosunkowo niewiele. Kenneth Reid wskazuje, że najwcześniejsze wspomnienie o pisarzu instytucjonalnym ${ }^{1}$ pochodzi od osoby, która choć znała go bezpośrednio, to opisała jego życie i twórczość dopiero kilkadziesiąt lat po jego śmierci². Mowa tutaj o dziele Johna Ramsaya - Scotland and Scotsmen in the Eighteenth Centrury — w którym kilka stron poświęcono osobie Erskine'a. Tezę o tym, że sława jego dzieła przysłoniła jego samego, podzielają nawet admiratorzy jego twórczości, a edytor wydanego w 1871 roku ósmego wydania Instytucji we wstępie wskazał, że życie

1 Mianem pisarzy instytucjonalnych określa się przedstawicieli szkockiej jurysprudencji, których traktaty prawnicze w ocenie przedstawicieli judykatury uzyskały status subsydiarnego źródła prawa. Znaczenie dzieł opierało się na wadze, jaką wyrażonym w nich opiniom autorów przypisywali ówcześni oraz późniejsi prawnicy — teoretycy i praktycy, stosując je jako przedmiot wykładu czy uzasadnienie wyroków. Dzieła instytucjonalne powstały w określonym momencie historycznym jako odpowiedź na potrzebę wykształcenia się odrębnego i nowoczesnego systemu szkockiego prawa prywatnego. Więcej zob. J.W. Cairns, Institutional Writings in Scotland Reconsidered, [w:] New Perspectives in Scottish Legal History, red. A. Kiralfy, H.L. MacQueen, London 1984; $\mathrm{K}$. Luig, The Institutes of National Law in the Seventeenth and Eighteenth Centuries, „Juridical Review" 1972, nr 17.

${ }^{2}$ K. Reid, John Erskine and the Institute of the Law of Scotland, „University of Edinburgh School of Law Research Paper" 2015, nr 26, s. 1. 
Erskine’a pozbawione było jakichkolwiek istotnych wydarzeń do tego stopnia, że można by je streścić jednym zdaniem ${ }^{3}$.

Nie jest to do końca w pełni uprawniona ocena. Choć w życiorysie Erskine'a próżno szukać udziału w najważniejszych wydarzeniach politycznych epoki lub w kształtowaniu się linii orzeczniczej najwyższego szkockiego sądu, jak to miało miejsce w przypadku jego wielkich poprzedników w osobach wicehrabiego Staira ${ }^{4}$ lub lorda Banktona ${ }^{5}$, to jednocześnie był on przykładem prawnika, który kilkunastoletnią praktykę adwokacką zamienił na uniwersytecką katedrę, a efektem połączenia doświadczeń z tych dwóch sfer aktywności były jedne z najwybitniejszych dzieł szkockiej jurysprudencji, które zasłużenie uzyskały rangę instytucjonalnych.

Ród Johna Erskine'a pochodził z prowincji Marr, regionu w północno-wschodniej Szkocji. Uchodził za rodzinę o szlacheckich korzeniach. John Erskine z Carnock urodził się 4 listopada 1695 — w roku śmierci innego wielkiego szkockiego prawnika, wicehrabiego Staira. Był synem pułkownika Johna Erskine'a z Carnock (trzeciego syna lorda Cardross) ${ }^{6}$ oraz jego drugiej żony — Anny Dundas $^{7}$. Na Johna — jako najstarszego syna — przeszedł w momencie śmierci jego ojca majątek położony w tej prowincji, w Carnock. Od nazwy tej siedziby rodowej wziął się zresztą przydomek późniejszego pisarza ${ }^{8}$.

Ojciec Erskine’a był żarliwym obrońcą religii prezbiteriańskiej, przez co zmuszony był emigrować do Niderlandów w drugiej połowie XVII wieku. Tam objął - w stopniu pułkownika — dowództwo nad regimentem piechoty należącym do księcia Wilhelma III Orańskiego. Pułkownik Erskine był jednym ze

3 J.B. Nicholson, Wstęp dla ósmego wydania dzieła Erskine'a, [w:] Institute of Law of Scotland, Edynburg 1871, s. V.

4 James Darlymple, wicehrabia Stair (1619-1695), szkocki adwokat, nauczyciel akademicki, lord prezydent Sądu Sesji oraz twórca jednego z podstawowych szkockich traktatów prawniczych: The Institutions of the Law of Scotland, deduced from its Originals and collated with the Civil, Canon and Feudal Laws and with the Customs of neighboring Nations (Edinburgh 1681). Wskazane dzieło doczekało się sześciu edycji (ostatniej z 1981). Dot Reid stwierdza, że praca Staira stanowi najistotniejsze wydarzenie w rozwoju szkockiego prawa prywatnego, a twierdzenia przedstawione w pracy — choć w znacznym zakresie już dziś nieaktualne - są obowiązujące z uwagi na znaczenie, jakie przypisują im sądy i doktryna prawna. Więcej zob. idem, Thomas Aquinas and Viscount of Stair: the Influence of Scholastic Moral Theology on Stair's Account of Restitution and Recompense, „Journal of Legal History” 2008, nr 29, s. 189.

5 Andrew MacDouall, lord Bankton (1685-1760), szkocki adwokat, wicedziekan szkockiej Rady Adwokackiej (Faculty of Advocates), u schyłku życia sędzia Sądu Sesji. Autor trzytomowego traktatu prawniczego wydanego między 1751 a 1753 rokiem: An Institute of the Laws of Scotland, które przedstawia całość regulacji prawnej szkockiego systemu prawnego w komparatystycznym ujęciu z regulacjami angielskimi i poglądami przedstawicieli kontynentalnej jurysprudencji.

6 T. Thomson, A Dictionary of Eminent Scotsmen, t. 3, Glasgow-Edinburgh-London 1853, s. 264.

7 J.W. Cairns, John Erskine of Carnock, [w:] Oxford Dictionary of National Biography, red. H.C.G. Matthew, B. Harrison, Oxford 2004, http://www.oxforddnb.com/view/article/8869 (dostęp: 15.09.2021).

${ }^{8}$ K. Reid, op. cit., s. 1. 
Szkotów ${ }^{9}$, którzy powrócili do ojczyzny w wyniku wydarzeń tak zwanej Chwalebnej Rewolucji w 1688 roku. Za swoją służbę otrzymał dowództwo regimentu piechoty królewskiej w randze podpułkownika oraz stanowisko dowódcy twierdzy — zamku Dumbarton ${ }^{10}$. W roku urodzenia przyszłego pisarza jego ojciec został wybrany dyrektorem Szkockiej Kompanii Handlu z Afryką i Indiami. Był przedstawicielem miasta Stirling do ostatniego szkockiego parlamentu, który w 1707 zdecydował o przyjęciu aktu unii, po 1707 roku był zaś wybierany do nowo utworzonego parlamentu brytyjskiego ${ }^{11}$. Zmarł w Edynburgu w styczniu 1743 roku w wieku 82 lat $^{12}$.

O wczesnych latach życia Johna Erskine'a nie posiadamy zbyt wielu informacji. Wiadomo, że w latach 1708-1711 uczęszczał na studia akademickie z zakresu prawa na uniwersytecie w Edynburgu. Istnieją również hipotezy, które mówią, że po ukończeniu studiów w Szkocji kształcił się przez pewien czas na uniwersytecie w Lejdzie ${ }^{13}$.

\section{Kariera zawodowa i późniejsze życie pisarza instytucjonalnego}

W roku 1719 został wpisany na listę szkockich adwokatów, a przedmiotem jego egzaminu wstępnego był 21 tytuł pierwszej księgi Instytucji Justynia$n a-$ De auctoritate tutorum ${ }^{14}$. O jego osiemnastoletniej praktyce adwokackiej (1719-1737) nie wiadomo wiele, a w ocenie Thomasa Thompsona świadczyć to może o tym, że jako adwokat Erskine nie należał do elity szkockiej palestry tego okresu $^{15}$. Wykazywał on z kolei zainteresowanie pracą samorządową — w latach 1720, 1723 oraz 1728 sprawował funkcję egzaminatora w ramach publicznego egzaminu wstępnego do szkockiej adwokatury, zaś w latach 1724 oraz 1732 został egzaminatorem $\mathrm{w}$ ramach niepublicznego egzaminu wstępnego z prawa rzymskiego. Także w roku 1732 został członkiem komisji, która miała przygotować nowy księgozbiór Rady Adwokackiej (Faculty of Advocates) ${ }^{16}$. Doświadczenie

${ }^{9}$ Wspomniany już lord Stair jako uchodźca polityczny, a następnie wysłannik szkockiego parlamentu przebywał w Niderlandach, gdzie poznał przyszłego króla angielskiego.

10 T. Thomson, op. cit., s. 264.

11 Ibidem.

12 R. Chambers, Biographical Dictionary of eminent Scotsmen, t. 2, Edinburgh 1837, s. 258.

13 K. Reid, op. cit., s. 2.

14 J.M. Pinkerton, The Minute Book of the Faculty of Advocates, t. 2. 1713-1750, Edinburgh 1980, s. 27.

15 T. Thomson, op. cit., s. 264.

${ }^{16}$ K. Reid, op. cit., s. 3. 
zdobyte w pracy adwokackiej oraz pełnione funkcje w strukturach samorządu edynburskiej adwokatury przygotowały go do przyszłej pracy akademickiej ${ }^{17}$.

W 1737 roku, w związku ze śmiercią Alexandra Bayne'a (1675-1737) — profesora prawa szkockiego na uniwersytecie w Edynburgu - Erskine został mianowany jego następcą ${ }^{18}$. Co ciekawe, nazwisko Erskine'a pojawiło się już w roku 1722, kiedy Rada Adwokacka w Edynburgu decydowała o kandydatach do obsadzenia nowo powstałej Katedry Prawa Szkockiego na edynburskim uniwersytecie, jednak w tym głosowaniu Erskine przegrał na rzecz swojego poprzednika, wspomnianego już Alexandra Bayne'a ${ }^{19}$. Erskine był również kandydatem na stanowisko profesora prawa cywilnego w wyborach w 1732 roku, ale ostatecznie uzyskał je Thomas Dundas (1706-1784) ${ }^{20}$. Dyskusyjna jest kwestia praktykowania przez Erskine'a jako adwokata w początkowych latach jego kariery akademickiej. Choć nie zakazywano akademikom pracy w zawodzie, to w przypadku Erskine'a wydaje się, że praca dydaktyczna i naukowa absorbowała go do tego stopnia, że zaniechał prowadzenia praktyki zawodowej ${ }^{21}$.

Wykłady z prawa szkockiego prowadzone przez Erskine'a miały się cieszyć bardzo dużym powodzeniem - frekwencja na nich znacznie przewyższała tę odnotowaną na wykładach jego poprzednika ${ }^{22}$. Swoje wywody początkowo oparł zresztą, podobnie jak Alexander Bayne, na podręczniku autorstwa sir George'a Mackenziego ${ }^{23}$. Kenneth Reid podaje, że metoda wykładu Erskine'a polegała na dokładnym przedstawieniu fragmentu pracy Mackenziego, po którym następował komentarz wykładowcy. Zachowane notatki z wykładów wskazują, że autorski komentarz wykładowcy nie dotyczył każdej części podręcznika, co miało oznaczać w przypadku danej partii tekstu jej aktualność oraz zgodność z poglądami wykładowcy ${ }^{24}$.

John Erskine zmarł 1 marca 1768 roku w majątku Cardross, który kiedyś należał do jego dziadka. Był dwukrotnie żonaty. Ze związku z Margaret Merville,

17 H. Moncreiff-Wellwood, Account of the Life and Writings of John Erskine, London 1818, s. 9.

18 Ciekawa jest przy tym sama procedura nominacji na stanowisko profesorskie. Choć formalnie organem je obsadzającym była rada miejska Edynburga, to wybór dokonywany był między dwoma kandydatami przedstawianymi przez Radę Adwokacką. Nominacja ta często bywała wyrazem uznania dla kandydata ze strony pozostałych adwokatów, a wspomniane uznanie, a nie kompetencje oraz umiejętności w zakresie nauczania prawa, decydowało o jej przyznaniu. W przypadku wyboru Erskine'a jego kontrkandydatem był James Balfour, który, jak podaje Thomas Thomson, nie był zainteresowany objęciem stanowiska profesorskiego. Zob. T. Thomson, op. cit., s. 265.

19 K. Reid, op. cit., s. 3.

20 J.W. Cairns, op. cit.

21 K. Reid, op. cit., s. 6.

22 R. Chambers, op. cit., s. 259.

23 G. Mackenzie, Institutions of Law of Scotland, Edinburgh 1681. Erskine z pewnością opierał się na nowym (pochodzącym z 1730 roku) wydaniu wspomnianego dzieła, które ukazało się nakładem pracy jego poprzednika na stanowisku profesora prawa szkockiego na edynburskim uniwersytecie.

24 K. Reid, op. cit., s. 4. 
z którą ożenił się w $1719^{25}$, urodził się w 1721 jego najstarszy syn — również John, który stał się później jednym z najsłynniejszych edynburskich kaznodziejów $^{26}$, oraz urodzona w 1722 roku córka Elisabeth ${ }^{27}$. Ze związku z Anną Stirling urodziło się aż pięcioro dzieci - czterech synów i córka ${ }^{28}$ : James (ur. w 1731), Robert (ur. w 1734), Thomas (ur. w 1742), David (ur. w 1763) oraz córka Christian (ur. w 1739) ${ }^{29}$. Po śmierci Erskine’a posiadłość w Carnock stała się własnością jego najstarszego syna Johna, zaś po jego bezpotomnej śmierci przejął ją David. Posiadłość w Cardross odziedziczył James ${ }^{30}$.

Ciekawy szkic charakteru pisarza przedstawił biograf jego syna Henry Moncreiff-Wellwood. W swoim dziele Account of the Life and Writings of John Erskine napisał, że ojciec przyszłego kaznodziei charakteryzował się cichym głosem oraz spokojną naturą, a przy tym rozległą wiedzą i metodycznością - co predestynowało go raczej do pracy naukowej niż do występowania przed sądem ${ }^{31}$. Cechował się też zupełnie innym charakterem niż jego ojciec, wspomniany już pułkownik Erskine, nie miał bowiem inklinacji do szerszego udziału w życiu publicznym kraju i skupiał się na swojej pracy pisarskiej ${ }^{32}$. John Erskine w odróżnieniu od swojego przodka cenił bardziej spokój działalności na uniwersytecie od kariery politycznej. Praca nad dziełem pochłonęła go to tego stopnia, że — jak wspomina John Ramsay, kronikarz życia znanych Szkotów — zdarzało się mu porzucać w trakcie wykonywaną czynność lub nawet przerywać ulubioną grę w karty w sytuacji, gdy naszła go jakaś refleksja, którą niezwłocznie pragnął zapisać ${ }^{33}$.

\section{Instytucje i Zasady — dwa dzieła instytucjonalne Johna Erskine'a}

W 1754 roku Erskine opublikował własną pracę wzorowaną na strukturze wspomnianego podręcznika George'a Mackenziego, na którym oparty był jego wykład prawa szkockiego. Praca początkowo została przygotowana w charakterze podręcznika pomocnego $\mathrm{w}$ ramach prowadzonego przez niego wykładu. Z czasem okazała się dziełem o znacznie szerszym zakresie zastosowania. Principles

25 Ibidem, s. 2.

${ }^{26}$ Więcej o życiu syna pisarza - Johna Erskine'a z Culdross - można przeczytać w jego biografii autorstwa Henry'ego Moncreiffa-Wellwooda, Account of Life and Writings of John Erskine, late one of the Ministers of Edinburgh, London 1818.

27 J.W. Cairns, op. cit.

28 T. Thomson, op. cit., s. 266.

29 J.W. Cairns, op. cit.

30 Ibidem.

31 H. Moncreiff-Wellwood, op. cit., s. 9.

32 Ibidem, s. 10.

33 J. Ramsay, Scotland and Scotsmen in the eighteenth century, t. 1, Edinburgh 1888, s. 148. 
of the Law of Scotland in the Order of Sir George Mackenzie's Institutions of that Law Erskine'a różniła się od wcześniejszej pracy Mackenziego nie tylko aktualnym stanem prawnym - zawierała ponadto omówienie kwestii pominiętych w oparciu o powzięte założenie o zwięzłości przygotowywanej pracy.

Praca Erskine'a doczekała się wielu wznowień z uwagi na precyzję, z jaką wyjaśniał on podstawowe zasady szkockiego systemu prawnego ${ }^{34}$. Drugie wydanie trafiło w ręce czytelników w 1757, a trzecie, które jednocześnie było ostatnim za życia autora, pojawiło się w roku 1764. W 1769 roku ukazało się czwarte wydanie - pośmiertne, w całości opracowane w oparciu o notatki autora. Ostatnie, 15 wydanie trafiło do druku w roku 1874, a jego redaktorem był William Guthrie. Sukces pracy nie został powtórzony przez dzieło Georga Josepha Bella o tożsamym charakterze i tytule ${ }^{35}$, a jak wskazuje K. Reid, pracą, która zastąpiła dzieło Erskine’a w procesie dydaktycznym, okazała się książka autorstwa Williama Murraya Gloaga (1865-1934) oraz Roberta Candlisha Hendersona (1874-1939) — Introduction to the Law of Scotland - wydana dopiero w $1927 \mathrm{roku}^{36}$.

W 1765 roku — po 28 latach nauczania na uniwersytecie w Edynburgu - Erskine przeszedł na emeryturę i poświęcił się pracy nad przygotowaniem do druku dzieła swojego życia, traktatu The Institutes of the Law of Scotland. W ocenie K. Reida duża część wspomnianej pracy powstała już przed rokiem 1764, na co wskazywać ma uwaga poczyniona przez autora we wstępie do trzeciego wydania Principles, w którym to zapowiedział pracę odpowiadającą na pytania pojawiające się na tle cytowanych w Principles orzeczeń ${ }^{37}$.

Praca nad dziełem została dokończona i zwieńczona drukiem w 1773 roku — pięć lat po śmierci autora. Do dzisiaj nie ma stuprocentowej pewności co do osoby edytora, który przygotował tekst do druku. Niektórzy historycy prawa szkockiego stwierdzają wprost ${ }^{38}$, że nie jest on znany, jednak inni — w oparciu o jeden z tekstów manuskryptu pracy — formułują tezę, że był nim czwarty syn pisarza, David ${ }^{39}$.

Thomas Thomson wskazuje, że choć praca nosiła pewne mankamenty wynikające z dokończenia jej przez inne osoby niż autor, to jednak jako całość wykazuje ten sam stopień precyzji co wcześniejsze dzieło Erskine’a, a zyskało ono tak duże uznanie przede wszystkim w oczach sędziów, iż trudno znaleźć pracę częściej cytowaną przez szkockie sądy jeszcze kilkadziesiąt lat później ${ }^{40}$.

W zakresie kolejnych wydań dzieła Erskine'a wypada zwrócić uwagę na znaczną częstotliwość reedycji. O ile dzieło Banktona nigdy nie doczekało się drugiego

\footnotetext{
34 T. Thomson, op. cit., s. 265.

35 G.J. Bell, Principles of Law of Scotland, Edinburgh 1829.

36 K. Reid, op. cit., s. 5.

37 Ibidem, s. 6.

38 D.M. Walker, Scottish Jurists, Edinburgh 1985, s. 204.

39 J. Ramsay, op. cit., s. 148.

40 T. Thomson, op. cit., s. 265.
} 
wydania, a pomiędzy wydaniem dzieła Staira za jego życia ${ }^{41}$ a opracowanym pośmiertnie minęło ponad 601 lat $^{42}$, o tyle praca Erskine'a cieszyła się tak dużym zainteresowaniem, że wydawano ją mniej więcej w dziesięcioletnich odstępach czasu, aż do przedostatniego wydania z 1838 roku. Druga edycja pod redakcją Alexandra Frasera Tytlera ukazała się w roku 1785, a zmiany w niej wprowadzone sprowadzały się w dużej mierze do uwzględnienia najnowszego orzecznictwa w formie przypisów. Redaktorem dwóch kolejnych edycji był Joseph Gillon, odpowiednio trzeciej z 1793 oraz czwartej z 1805 roku $^{43}$. Dzieło cieszyło się tak dużym zainteresowaniem, że czwarta edycja doczekała się dwóch dodruków w 1812 z uwagi na wyczerpanie się do 1811 roku dostępnych w sprzedaży kopii czwartego wydania. Kolejne miało miejsce po gruntownej aktualizacji dokonanej przez adwokata Jamesa Ivorego - pierwszy tom ukazał się w 1824, a drugi w $1828 \mathrm{roku}^{44}$.

Szczegółowe notatki poczynione w dziele Erskine'a przez Jamesa Ivorego zostały w znacznej części zredukowane przez kolejnego edytora - Alexandra Macallana, który chciał nadać dziełu mniej naukowy, ale jednocześnie bardziej przystępny dla praktyka charakter, co uczynił w przygotowanej przez siebie i wydanej drukiem w 1838 roku edycji dzieła. Sam tekst pozostał jednak — jak w poprzednich edycjach - nienaruszony, a praca edytorska ograniczała się do aktualizacji i redakcji przypisów ${ }^{45}$. Ostatnie wydanie Instytucji Erskine'a ukazało się w 1871 roku pod redakcją Badenacha Nicolsona ${ }^{46}$. Jednocześnie edytor ostatniego wydania wskazywał na ogromne trudności w aktualizacji treści dzieła ze względu na znaczny przyrost prawa stanowionego oraz dorobku szkockiej judykatury ${ }^{47}$.

Istnieje kilka hipotez na temat tego, dlaczego Erskine opublikował swoją pracę tak późno, a nie w trakcie kariery akademickiej. Najbardziej rozpowszechniona z nich mówi o tym, że opublikowana w latach 1751-1753 praca lorda Banktona nie zostawiła miejsca na podobne dzieło na, skądinąd, niewielkim rynku szkockiej literatury prawniczej. Za tą tezą może przemawiać fakt, że praca o podobnym profilu wydana w 1760 roku - pierwszy tom dzieła George'a Wallace'a System of the Principles of the Law of Scotland - miała sprzedać się jedynie w 40 egzemplarzach. Jednocześnie brak drugiej edycji pracy Banktona, nad którym miał pracować przed śmiercią, otwierał drogę do wydania nowej, o przekrojowym charakterze ${ }^{48}$.

41 Wydanie drugie $\mathrm{z} 1693$ roku.

42 Wydanie trzecie z 1759 roku.

43 J. Watkins, F. Shobert, A Bibliographical Dictionary of the Living Authors of Great Britain and Ireland: Comparising Literary Memoirs and Anecdotes of Their Lives; and a Chronological Register of Their Publications, with the Number of Editions Printed; Including Notices of Some Foreign Writers Whose Works Have Been Occasionally Published in England, London 1816, s. 129.

${ }^{44}$ K. Reid, op. cit., s. 9.

45 Ibidem, s. 10.

46 T. Thomson, op. cit., s. 265.

47 D.M. Walker, A Legal History of Scotland, Edinburgh 1998, s. 1047.

48 D.M. Walker, Scottish..., s. 305. 
Jako wadę pracy czasami podnosi się jej zbyt akademicki styl oraz wyraźny brak wiedzy autora w zakresie pewnych aktualnych problemów prawnych ${ }^{49}$. Jest to pokłosiem różnic w historii kariery zawodowej Erskine'a i autorów wcześniejszych ${ }^{50}$ dzieł instytucjonalnych, którzy wciąż byli praktykami w momencie pisania swoich prac. Wspomniana „wada” może być jednak również zaletą dzieła, które dokonuje pierwszej analizy instytucji prawa szkockiego przede wszystkim z punktu widzenia nauki prawa. We wspomnianych wcześniejszych dziełach przeważało wykorzystanie metody komparatystycznej - Stair poczynił spostrzeżenie o wpływie kontynentalnej jurysprudencji na kształt norm prawa szkockiego, zaś Bankton w szerokim stopniu wskazał na rzymski i angielski rodowód prawa szkockiego. Na tym tle trzeba więc docenić Erskine'a, który w swojej pracy skupił się na samej istocie prawa szkockiego, starając się ukazać go w jak najczystszej postaci.

Dzieło Erskine'a wpisywało się przy tym silnie w nurt prawa natury, przedstawiało bowiem szkocki system prawny w oparciu o prymat prawa naturalnego względem stanowionego (positive law), które stanowić mogło jedynie formę uszczegółowienia i nadania ram wspomnianemu prawu naturalnemu ${ }^{51}$.

Za najsłabszą część omawianego dzieła uważa się tę poświęconą prawu handlowemu. Daleko Erskine'owi w tym zakresie do jego poprzedników, a braki w tym aspekcie być może stały się impulsem, który zadecydował o napisaniu przez Georga Josepha Bella jego najsłynniejszego dzieła - Commentaries on the Law of Scotland and on the Principles of Mercantile Jurisprudence z $1810 \mathrm{roku}^{52}$, będącego jednocześnie ostatnim dziełem instytucjonalnym.

Powyżej wskazane mankamenty nie wpłynęły na ogólny odbiór dzieła w szkockim środowisku prawniczym. Już w roku pierwszego wydania tezy Erskine'a zostały przywołane przez adwokata w sądzie ${ }^{53}$, a wyczerpywanie się kolejnych nakładów wskazuje na nieustającą popularność dzieła. Kenneth Reid tłumaczy sukces jasnością i przystępnością tekstu, który mógł być w łatwy sposób wykorzystywany dla celów praktyki sądowej. Nie bez znaczenia był również zastosowany przez Erskine'a układ tekstu, który korespondował z jego Principles oraz wcześniejszym dziełem Mackenziego. „Wychowani” na tych tekstach prawnicy szkoccy nie mieli problemu z poruszaniem się po znacznie obszerniejszych w swojej treści Instytucjach. Kenneth Reid stawia również tezę, że o sukcesie pracy zadecy-

49 R. Chambers, op. cit., s. 260.

50 Mowa tutaj oczywiście o takich osobach, jak wicehrabia Stair oraz lord Bankton.

51 A. Broadie, The Scottish Enlightment, Edinburgh-London-New York-Melbourne 2010, s. $598-599$.

52 K. Reid, op. cit., s. 13.

53 Sprawa lorda Fredericka Cambella przeciwko Dawidowi Scottowi, w której wyrok zapadł 8 grudnia 1773 roku. Zob. W.M. Morison, The Decisions of the Court of Session: From Its First Institution of the Present Time: Digested Under Proper Heads, in the Form of a Dictionary, t. 16, Edinburgh 1804, s. 13535. 
dowała chronologia ukazania się względem pracy Banktona; przypominając, że praca ta - w odróżnieniu od omawianego dzieła - ukazała się tylko w jednym wydaniu, stwierdza, że obydwa dzieła mógł czekać odmienny los, gdyby pozycja Banktona ukazała się 20 lat po pracy Erskine'a. Z uwagi na niepojawienie się na przestrzeni 60 lat od wydania Instytucji Erskine'a kolejnego dzieła omawiającego szkocki system prawny w sposób wyczerpujący i holistyczny jedyną receptą była aktualizacja najnowszej pracy. Obydwa dzieła zostały w swoich funkcjach zastąpione przez prace Georga Josepha Bella - jednego z następców Erskine'a na stanowisku profesora prawa szkockiego na uniwersytecie w Edynburgu. Wydane w 1829 roku Principles Bella spełniały funkcje podręcznika wprowadzającego młodych adeptów w arkana szkockiego systemu prawnego, zaś Commentaries odpowiedziały na potrzeby doktryny prawnej, której brakowało syntetycznego podejścia do takich instytucji prawnych związanych z prawem handlowym, jak upadłość, powiernictwo, spółka czy papiery dłużne ${ }^{54}$.

Struktura, nazwa i rola Instytucji Erskine'a nawiązują wprawdzie do ról ich antycznego przodka, jednak układ tekstu w największym stopniu koreluje z podziałem zastosowanym we wspomnianej już pracy Mackenziego, który wprowadził pewne odstępstwa od klasycznej struktury justyniańskich instytucji. Polegały one na przeniesieniu zagadnień związanych z dziedziczeniem z księgi drugiej do trzeciej, a problematyki odpowiedzialności deliktowej także do księgi trzeciej z księgi czwartej. Dzieło Erskine’a podejmuje zagadnienie całości szkockiego systemu prawnego, dlatego w czwartej księdze poświęconej prawu procesowemu zawarto również, na 45 stronach, problematykę prawa karnego ${ }^{55}$.

Erskine w znacznie większym stopniu niż wcześniejsi pisarze instytucjonalni odwoływał się do orzeczeń sądowych, którym choć nie nadawał generalnie mocy wiążącej przy orzekaniu przyszłych spraw, to jednak - jeżeli były powszechnie akceptowane oraz tworzyły zwyczaj w kwestiach, w których nie było wyraźnej normy prawnej - mogły stanowić część niepisanego prawa (unwritten law) ${ }^{56}$.

Kolejnym istotnym źródłem cytowanym przez Erskine’a była szkocka literatura prawnicza. Przywoływane jest dzieło Staira, choć, jak wskazuje K. Reid, Erskine nie traktował tej ponad stuletniej wtedy pracy z nadzwyczajną rewerencją i nie bał się kwestionować opinii, z którymi się nie zgadzał ${ }^{57}$. W pracy występują ponadto odniesienia do dzieła instytucjonalnego z zakresu prawa feudalnego Craiga z Riccarton oraz źródła inspiracji dla Principles — czyli dzieła Mackenziego. W ocenie K. Reida Erskine w znaczenie większym stopniu wykorzystuje dzieła literatury siedemnastowiecznej niż twórczość autorów sobie współczesnych. Największa liczba cytowań jednego dzieła odnosi się do Instytucji Banktona, jednak

54 K. Reid, op. cit., s. 11.

55 Ibidem, s. 13.

56 J. Erskine, The Institute of the Law of Scotland, Edynburg 1773 (oraz późniejsze wydania), 1.1.47.

57 K. Reid, op. cit., s. 16. 
w większości wskazują one na źródło polemiki ze wskazanym autorem niż na aprobatę jego stanowiska ${ }^{58}$.

W zakresie cytowania prawa rzymskiego Erskine należy do tych autorów instytucjonalnych, którzy stosowali to źródło odniesienia w sposób częsty, co prawdopodobnie związane jest z bardziej naukowym charakterem jego dzieł. Jednocześnie Erskine prawo rzymskie traktował ze znacznie większym dystansem niż Stair czy Bankton - dla nich stanowiło budulec norm prawnych w sytuacji nieistnienia odpowiedniej regulacji w prawie szkockim, natomiast Erskine wskazuje przede wszystkim na sytuacje, w których było ono źródłem inspiracji szkockiej regulacji. Ten kierunek argumentacji stał się wyjątkowo ważny po traktacie unijnym z 1707 roku, wobec istniejącej groźby anglicyzacji szkockiego prawa prywatnego. Paradoksalnie to zewnętrzne zagrożenie stało się impulsem dla nowej fali romanizacji prawa szkockiego, a szkoccy prawnicy w prawie rzymskim widzieli alternatywę, która umożliwiała zachowanie suwerenności własnego systemu prawnego ${ }^{59}$.

Samodzielność prawa szkockiego jako systemu prawnego i metoda odwoływania się do źródeł prawa rzymskiego korespondują ze sposobem nawiązywania Erskine'a do źródeł nowożytnej doktryny europejskiego ius commune, którym nie nadawał powszechnie obowiązującego charakteru w ramach systemu źródeł prawa szkockiego, jednak niewątpliwie cenił je jako nośnik logicznych zasad oraz perswazyjnego przekazu. Brak odwołań do dzieł Vinniusa (które w prywatnej korespondencji Erskine bardzo zachwalał) oraz skromne odwołania do prac Voeta, Grocjusza i Puffendorfa (i to tylko tych napisanych po łacinie) wskazują, że dzieło nie ma w pełni komparatystycznego charakteru, a wspomniane odwołania cechuje co do zasady perswazyjny charakter w pracy obrazującej kształt szkockiego systemu prawa prywatnego w połowie XVIII wieku ${ }^{60}$.

$\mathrm{Z}$ biegiem czasu rola Instytucji Erskine'a uległa zasadniczej zmianie. Ostatnie wydanie nie było już wiodącą pracą z zakresu szkockiej jurysprudencji, a stanowiło pomnik zasad prawnych, które opisywane jako instytucje prawa w pierwszym wydaniu utrwaliły się z biegiem czasu, stanowiąc swoisty fundament systemu prawnego. Kenneth Reid wskazuje, że w tym wymiarze należy upatrywać zmiany charakteru dzieł instytucjonalnych z prac stanowiących holistyczny opis systemu prawnego na te będące historycznym potwierdzeniem kształtowania się zasad prawnych $^{61}$. Choć dzieło Erskine'a musiało w oczach wielu późniejszych prawników ustępować legendarnej rozprawie Staira oraz najbardziej aktualnym pracom Bella, to jednocześnie nie ulega wątpliwości, że w swoim czasie było ono wyjątkowym i wartościowym wkładem nie tylko w naukę prawa szkockiego, ale istotnym czynnikiem rozwoju szkockiego systemu prawnego jako hybrydowego.

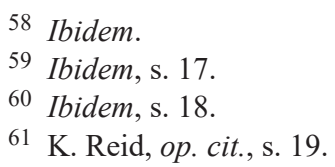




\section{Bibliografia}

\section{Dzieła instytucjonalne i szkockie traktaty prawne (wskazane w treści artykułu, w układzie chronologicznym)}

Craig T., Ius feudale, Edinburgh 1655.

Darlymple J. [Viscount of Stair], Institutions of the Law of Scotland, Edinburgh 1681 (oraz późniejsze wydania).

Mackenzie G., Institutions of Law of Scotland, Edinburgh 1681.

Macdouall A. [Lord Bankton], Institutes of the Law of Scotland in Civil Rights, Edinburgh 1751-1753.

Erskine J., Principles of the Law of Scotland, Edinburgh 1754 (oraz późniejsze wydania).

Erskine J., The Institute of the Law of Scotland, Edinburgh 1773 (oraz późniejsze wydania).

Bell G.J., Commentaries of the Laws of Scotland in the Relation to Mercantile and Maritime Law, Moveable and Heritable Rights and Bankruptcy, Edinburgh 1810.

Bell G.J., Principles of Law of Scotland, Edinburgh 1829.

\section{Literatura}

Broadie A., The Scottish Enlightment, Edinburgh-London-New York-Melbourne 2010.

Cairns J.W., Institutional Writings in Scotland Reconsidered, [w:] New Perspectives in Scottish Legal History, red. A. Kiralfy, H.L. MacQueen, London 1984.

Cairns J.W., John Erskine of Carnock, [w:] Oxford Dictionary of National Biography, red. H.C.G. Matthew, B. Harrison, Oxford 2004.

Chambers R., Biographical Dictionary of eminent Scotsmen, t. 2, Edinburgh 1837.

Luig K., The Institutes of National Law in the Seventeenth and Eighteenth Centuries, „Juridical Review" 1972, nr 17.

Moncreiff-Wellwood H., Account of the Life and Writings of John Erskine, London 1818.

Morison W.M., The Decisions of the Court of Session: From Its First Institution to the Present Time: Digested Under Proper Heads, in the Form of a Dictionary, t. 16, Edinburgh 1804.

Nicholson J.B., Introduction to Institute of Law of Scotland, Edinburgh 1871.

Pinkerton J.M., The Minute Book of the Faculty of Advocates, t. 2. 1713-1750, Edinburgh 1980.

Ramsay J., Scotland and Scotsmen in the Eighteenth Century, Edinburgh 1888.

Reid D., Thomas Aquinas and Viscount of Stair: the Influence of Scholastic Moral Theology on Stair's Account of Restitution and Recompense, „Journal of Legal History” 2008.

Reid K., John Erskine and the Institute of the Law of Scotland, „University of Edinburgh School of Law Research Paper" 2015, nr 26.

Thomson T., A Dictionary of Eminent Scotsmen, t. 3, Glasgow-Edinburgh-London 1853.

Walker D.M., A Legal History of Scotland, Edinburgh 1998.

Walker D.M., Scottish Jurists, Edinburgh 1985.

Watkins J., Shobert F., A Bibliographical Dictionary of the Living Authors of Great Britain and Ireland: Comparising Literary Memoirs and Anecdotes of Their Lives; and a Chronological Register of Their Publications, with the Number of Editions Printed; Including Notices of Some Foreign Writers Whose Works Have Been Occasionally Published in England, London 1816. 


\title{
John Erskine of Carnock (1695-1768) — jurist, professor at the University of Edinburgh, institutional writer
}

\begin{abstract}
Summary
The article is an attempt to describe John Erskine - a Scottish advocate, the second person to hold the chair of Scottish law at the University of Edinburgh, and an institutional writer. The author of An Institute and Principles largely abandoned the comparative approach of his predecessors in favour of a systematic interpretation of Scottish law enriched with scholarly reflection on its nature, whilst taking into proper account the current state of Scottish case law. Erskine's works have not only provided a foundation for the education of many generations of Scottish jurists, but having found recognition in the eyes of Scottish jurisprudence, they have secured for themselves the status of a subsidiary source of law, and for their author, a great deal of respectability.
\end{abstract}

Keywords: Scottish law, mixed jurisdictions, institutional writer, John Erskine, Principles of the Law of Scotland, An Institute of the Law of Scotland.

\section{John Erskine von Carnock (1695-1768) - Rechtsanwalt, Professor an der Universität Edinburgh, institutioneller Schreiber}

\section{Zusammenfassung}

Gegenstand des Beitrags ist der Versuch die Gestalt von John Erskine zu schildern. Er war schottischer Rechtsanwalt, zweite Person, die den Posten des Professors für schottisches Recht an der Universität Edinburgh bekleidete und zugleich ein institutioneller Schreiber. Der Verfasser von Institutionen und Grundsätzen verzichtete überwiegend auf die komparatistische Auffassung seiner Vorgänger zugunsten des systematischen Vortrages des schottischen Rechts, bereichert um wissenschaftliche Reflexion seinen Charakter betreffend, unter gleichzeitiger Berücksichtigung des aktuellen Standes der schottischen Rechtsprechung. Die Werke von Erskine stellten nicht nur ein Fundament der Edukation vieler Generationen schottischer Juristen dar, aber nachdem sie durch die schottische Jurisprudenz anerkannt wurden, sicherten sie sich auch den Status einer subsidiären Rechtsquelle, und dem Autor dieser Werke — großen Respekt.

Schlüsselwörter: schottisches Recht, hybrides Rechtssystem, institutioneller Schreiber, John Erskine, Principles of the Law of Scotland, The Institutes of the Law of Scotland. 